\title{
Stage Ois Urethral Cancer AJCC v7
}

National Cancer Institute

\section{Source}

National Cancer Institute. Stage Ois Urethral Cancer A/CC V7. NCI Thesaurus. Code C4531.

Stage Ois includes: (T is, NO, MO); ( $\mathrm{T}$ is pu, NO, M0); ( $\mathrm{T}$ is pd, NO, MO). T is: Carcinoma in situ. T is pu: Carcinoma in situ, involvement of the prostatic urethra. T is pd: Carcinoma in situ, involvement of the prostatic ducts. NO: No regional lymph node metastasis. MO: No distant metastasis. (AJCC 7th ed.) 